\title{
ETNOGRAPHY OF COMMUNICATION OF ANIMAL LOVERS COMMUNITY JAKARTA
}

\author{
Oleh: \\ Lusyana $^{1}$ \\ Imam Nuraryo ${ }^{2}$
}

\begin{abstract}
This research examines ethnography of communication in Jakarta Dog Lovers can be divided into three main problems: first is a form of communication activities undertaken in the community, second is the communication components that make up the communication activities, and third is the communication competencies of community members while performing a communication activity.

This study was studied by looking at the theory and method of ethnography of communication from Dell Hymes. The method of communication ethnography is one of the study of communication ethnography of some qualitative research studies (interpretive or constructivistparadigm), which is found in the discovery of various communication patterns used by humans in a speech society

The data collection techniques utilized is through the method of introspection, in-depth interviews, participant observation, and document analysis. The techniques of data analysis in this study uses the gradual advancement of 12-step flow analysis research approach created by James $P$. Spradley.

The results of this research are divided into three main points based on the research objectives. First is the form of the communication activities in the community of Jakarta Dog Lovers as seen on the public gathering conducted routinely every weekend, charities, active participation on campaign events, as well as providing education to inform the general members of the public about the issues surrounding dogs. Second, there are ten components that make up the concept of communication activities. Third, the competencies of the members when interacting with fellow peers of their community.

This research concludes that the communication activities conducted by the general public of the community is supported by the presence of communication elements and competencies of the members in interacting with one another in Jakarta Dog Lovers Community. This context is evidence of ethnography or cultural cultivation that occurs in Jakarta Dog Lovers. Researchers also suggest that research on Jakarta dog lovers community topics will be more developed in the future.
\end{abstract}

Key words: Ethnography of Communication, Community, Jakarta Dog Lovers.

\footnotetext{
${ }^{1}$ Alumni Program Studi Ilmu Komunikasi - Institut Bisnis dan Informatika Kwik Kian Gie

${ }^{2}$ Alamat kini: Institut Bisnis dan Informatika Kwik Kian Gie, Jn Yos Sudarso Kav. 87 Sunter, Jakarta 14350 Penulis untuk Korespondensi: Telp. (021) 65307062 Ext. $705 . \quad$ E-mail: imam.nuraryo@kwikkiangie.ac.id.
} 


\section{INTRODUCTION}

Most people in the current era have a penchant for interacting and socializing with one another. Interacting and socializing are basic needs that have existed in every human being since birth into the world. In terms of interaction, humans need togetherness and cohesiveness to maintain harmony with each other.

Togetherness and solidarity are important in maintaining a social interaction relationship so that it can run smoothly and avoid various conflicts. Mutual understanding between individuals is necessary to create peace and peace in a society. One way to strengthen togetherness and cohesiveness that can be done is by forming a community.

According to Alyusi (2016: 29), community is a social group of several organisms that share the environment, and generally have the same interests. These same interests can be seen in the same hobbies and interests, the same profession, or the same background. The benefits of forming a community can be felt because members can exchange important information.

Communication also plays a very important role in creating a harmonious relationship in a community. According to Rogers and Kincaid (in Cangara, 2010: 20), communication is a process in which two or more people form or exchange information with each other, which in turn will arrive at a deep mutual understanding.

Communication is one of the keys in building a relationship in society, especially in the community. The idea of community refers to an association of people who have the same cultural, ideological, socioeconomic background, geographic boundaries, hobbies and so on, who meet regularly by holding regular gathering activities.
One of the phenomena of the formation of a community can be seen in the animal lover community in Indonesia. This animalloving community in Indonesia originated from their love for domestic animals, especially dogs. In everyday life, dogs are known as pets that have high intelligence.

The average dog has a level of intelligence equivalent to a 2 year old child. If trained properly, dogs can understand what humans command, for example in terms of looking for items or even being trained as a guard dog. Dogs also have very high fidelity. This makes most people interested in adopting or raising dogs as friends.

This penchant for interacting and socializing and the people's interest in adopting or raising dogs has resulted in the formation of a community of dog lovers. The dog lovers community is a social group that is formed on the basis of the hobby or love of a group of people for dogs.

One of the well-known dog lovers communities can be seen in the Jakarta Dog Lovers Community in the DKI Jakarta area. This community was originally a small dog lovers group formed by Sandy Halin Perdana and Steffhen Markus in 2014. Then, in 2015, this small dog lovers group turned out to be a large group with a goal of promoting dogs and educating dog owners to become responsible dog owners based across communities, groups or groups of dog lovers (anjingkita; 2017; 2017).

The Jakarta Dog Lovers Community has a slogan, "We Are Dog Lovers, Together We Can". This community was founded with the intention of strengthening the relationship between dog owners in various communities, independent dog owners, animal activists, animal volunteers, dog hobbyists and animal lovers in general. It aims to share and learn about how to educate, train and care for dogs which then develop as part of the working community, empowering the potential of all 
members for the welfare of pet dogs, so that it benefits the family, community, nation and state (Jakartadoglovers; 2017).

In achieving these aims and objectives, the Jakarta Dog Lovers Communi ty encourages its members to be able to socialize and provide education about education and dog care in the family and community environment. Then, holding activities or activities that aim to explore the potential of the community from the potential of each of its members, carry out education through social activities and positive events through collaboration between dog lover communi ti es and other animal lover communities (Jakartadoglovers; 2017).

Activities held by the Jakarta Dog Lovers Community are routine gathering activities every weekend, holding charity activities, participating and being active in campaign activities, as well as conducting educational activities to the public and members of the community about dogs.

The media used by the Jakarta Dog Lovers Community to educate and provide information are Facebook, Instagram, Website, and Telegram messenger. These various media are used to provide information and education for dog lovers, especially for members of the Jakarta Dog Lovers Communi ty (Jakartadoglovers; 2017).

The media most often used in establishing relationships between member s of the Jakarta Dog Lovers Community is through the Telegram messenger and Instagram media. Telegram messenger is used to maintain good communication relations between members. While the Website, Facebook and Instagram are used to share various information about dogs.

This phenomenon triggers the desire of researchers to research and study communication activities, communication components, and communication competencies that exist in the Jakarta Dog
Lovers Community. Researchers want to see how the process of delivering and receiving messages in communication activities carried out by this community. So that in this study, the researcher took the research title, "Ethnography of Jakarta Dog Lovers Communi ty Communication".

This research was studied by looking at the ethnographic theory and method of communication from Dell Hymes. The ethnographic method of communication is one of the ethnographic studies of communication from a number of qualitative research studies (interpretive or constructivist paradigms), which specialize in the discovery of various communication patterns used by humans in a speech society (Kusw arno, 2008: 2).

The ethnographic method of communication is used to see the communication patterns used by the Jakarta Dog Lovers Community. This can be seen through three aspects, namely the form of communication activities, communicati o $n$ components in the ethnographic perspective of communication, and communication competencies that exist in the Jakarta Dog Lovers Community.

This research is a research with qualitative methods - ethnography of communication. The data collection technique was carried out through introspection, participant observation who is a researcher who works directly as a member of the community, conducting in-depth interviews, and analyzing documents.

The data analysis technique used in this study was Spradley's twelve-step forward research path. The stages in the twelve steps of the progressive research flow are: assigning informants, interviewing informants, making ethnographic notes, asking descriptive questions, conducti ng ethnographic interview analysis, making domain analysis, asking structural questions, 
making taxonomic analysis, asking contrast questions, making component analysis, finding cultural themes, and ethnographic writing. In these stages can produce an original ethnographic description (Spradley, 2007: 63).

From this ethnographic communicati o $n$ research, it is hoped that researchers can describe how communication patterns are formed in the Jakarta Dog Lovers Communi ty.

\section{Ethmography of Communication}

The ethnographic study of communication is a development of linguisti c anthropology which is understood in the context of communication. This study was first introduced by Dell Hymes in 1962, as a criticism of linguistics which focuses too much on the physical language alone (Kuswarno, 2011: 11).

Basically, ethnography is a knowledge building that includes research techniques, ethnographic theory, and various kinds of cultural descriptions. Ethnography means building a systemic understanding of all human culture and the perspectives of people who have studied that culture (Kuswarno, 2011: 32).

According to Kriyantono (2015: 85), ethnography has developed and is widely applied in a wider scope, not limited to efforts to describe and analyze the culture and language of a particular group or society. Ethnography is currently widely applied to broader cultural groups, not limited to certain communities or ethnic groups.

Ethnography which focuses on patterns of communication behavior as one part of a cultural system, which functions in the whole cultural context and which functions to connect patterns of parts of other cultural systems. Therefore this communication ethnographic study examines three main components: language, communication, and culture (Kriyantono, 2015: 90).

Ethnography of communication (ethnography of communication) is an assessment of the role of language in the communicative behavior of a society, namel y the ways in which language is used in societies of different cultures. It is called communication ethnography because Hymes thinks that the frame of reference for giving a place for language in a culture should be focused on communication, not on language (Kuswarno, 2011: 11).

Hymes (in Kuswarno, 2011: 14) explains the scope of the ethnographic study of communication, namely communicati on patterns and functions, the nature and definition of speech society, ways of communicating, components of communicative competence, the relationship of language to world views and social organization, and universe and linguistic and social inequality.

According to Littlejohn and Foss (2012: 460), communication ethnography is a simple ethnography application method in the communication patterns of a group. The interpreter tries to make the form of communication used by members in a community or culture can be accepted with common sense. Ethnography of communication looks at 5 aspects.

The first aspect, the communication patterns used by a group. Second, interpreting all of these communication activities exists for groups. Third, when and where group members use all of these activities. Fourth, how communication practices create a community. And fifth, the diversity of codes used by a group.

\section{Community}

According to Alyusi (2016: 29), community is a social group of several organisms that share the environment, 
generally having the same interests. Community comes from the Latin Communi tas which means "equality" and can then be reduced to communis which means "the same, shared by all or many".

The definition of community according to Hermaw an (2008: 21) is a group of people who care for each other more than they should, where in a community there is a close personal relationship between members of the community because of the same interests and values.

\section{RESEARCH METHODS}

The subjects in this study were all people who served in the organizational structure as well as members who are members of the Jakarta Dog Lovers Community. In the Jakarta Dog Lovers Community, it is divided into two member categories, namely the category of regular members and full members. Regular members are people who only belong to the group chat on Telegram messenger and number around 250 people.

While full members are people who are members of the chat group on Telegram messenger and have a member card and are registered in the database of approximatel y 100 people. Full members have privileges, such as: getting official communi ty shirts as an affirmation of community member s, getting special treatment at merchants in collaboration with the community and the Jakarta Animal Lovers Foundation, as well as special prices for purchasing merchandise produced by the community and special prices for dog training at CHAMBARAYA DTC (Jakartadoglovers; 2017).

The members who are members of the Jakarta Dog Lovers Community consist of various ethnic groups and the majority consist of Javanese, Batak, Betawi, Manado, Ambon, and Chinese ethnic groups. They live in the
Jabodetabek area (Jakarta, Bogor, Depok, Tangerang, and Bekasi). Religions owned by members of the Jakarta Dog Lovers community consist of various religions, such as: Islam, Christianity, Hinduism, and Buddhism As for them, they work as lawyers, police, private employees, civil servants, students, and entrepreneurs.

\section{Re se arch De sign}

The method used in this research is a qualitative method of communication ethnographic studies, because this method can describe, explain, and build relationships of the categories and data found. This is in accordance with the objectives of the ethnographic study of communication to describe, analyze and explain the communication behavior of a social group (Kusw arno, 2011: 86).

According to Kriyantono (2015: 90), the ethnographic method of communication is the application of the ethnographic method to study communication patterns, such as what is communicated, how to communicate, communication situations, communicatio $n$ rules, communication components, and communication functions. in the community.

Qualitative research according to Bogdan and Taylor (in Kuswarno, 2011: 30) is a scientific approach that is directed at settings and individuals holistically or as a whole. So in this case, it is not permissible to isolate individuals or organizations into variables or hypotheses, but it is necessary to view them as part of a need.

Qualitative research will guide communication ethnography to understand how language, communication, and culture work together to produce distinctive communication behaviors. Ethnography of communication is also a science as well as a research method in social science. Ethnography of communication contains 
anthropological values, as well as linguistic and communication (Kuswarno, 2011: 31).

\section{Data Collection Technique}

Data collection techniques in this study are the methods used by researchers to find data relevant to the research theme. According to Kuswarno (2011: 48-59), there are 5 data collection methods in ethnogr aphy of communication, namely introspection, participant observation, in-depth interviews, participant observation, and document analysis.

In this study, researchers used 4 of the five data collection methods, namely introspection, participant observation, indepth interviews, and document analysis. The following is an explanation of each of these data collection methods.

\section{Data Analysis Technique}

The data analysis technique used was a twelve-step data analysis technique from Spradley's gradual advance to produce an original ethnographic description. Here are the first twelve steps of Spradley's (2007: 65306) first steps.

\section{RESULTS AND DISCUSSION}

Based on the discussion of research findings sourced from the researcher's introspection while in the Jakarta Dog Lovers Community, field observations, in-depth interviews with informants, and document analysis, the researchers found the results of the ethnographic communication research in the Jakarta Dog Lovers Community in carrying out each of its activities are as follows.

The Jakarta Dog Lovers Community is a community in which members who own dogs of various breeds are joined. In this community there is no limit to the breed of dog, both mongrel and purebred dogs, all can join this community.

There are 4 (four) types of activities carried out by the Jakarta Dog Lovers Community, namely routine gathering activities every weekend, holding charity activities, participating and being active in campaign activities, and conducting educational activities for members and the community. The researcher found that there were various forms of communication activities in each of the activities carried out by the Jakarta Dog Lovers Community.

The gathering activity in the Jakarta Dog Lovers Community is a routine activity every weekend that is used as a place to gather, socialize, and exchange ideas with various information or experiences about the world of dogs. Through this gathering activity, members or participants will be more informed about dogs.

Charity activity is one of the places used in holding social service events or raising funds to collect donations that will be donated to dogs in need. In this charity activity, members or participants are invited to care more about domestic animals, especially dogs.

This activity is carried out in order to create the welfare of domestic animals. In this activity, usually each member or participant holds a flashmob dance and brings a poster on display. Members or participants usually wear a black dress code.

The Jakarta Dog Lovers Community participates and is active in campaign activities that are routinely held every month. The educational activity by the Jakarta Dog Lovers Community is an activity aimed at educating the public and members to become more committed and responsible dog owners in caring for and caring for dogs. Educational activities can be carried out in gathering activities, campaign activities, and can be done by distributing content in the form of 
photos and videos through social media owned by the community, especially on Facebook and Instagram

The communication components are interrelated with each other in forming a communication activity that is in the Jakarta Dog Lovers Community. The 10 components of communication are genres or types of communicative events, topics of communicative events, purpose and function of events, settings, participants, message form message content, action sequences, interaction rules and interpretation norms.

Genres or types of communicative events in the activities in the Jakarta Dog Lovers Community are divided into 4, namely discussion, charity, campaigns, and education. Each of these four genres or types of communicative events exists in every activity carried out by the communi ty. This can be seen in the discussion genre which is more often found in gathering activities and conversations via the Telegram messenger chat group.

Genre charity exists in social service activities and fundraising activities. Campaign genres that exist in campaign activities, as well as educational genres that exist in every educational activity.

The topic of communicative events in the Jakarta Dog Lovers Communi ty cannot be separated from the discussion about dogs. The topic of this communicative event usually occurs both when meeting face-toface, as well as conversations via social media, especially in the Telegram messenger chat group.

Researchers found the topic of communication events in the Jakarta Dog Lovers Community. The first is the identification of the dog, this includes the name, gender, breed and age of the dog. The topic of the second communication event is information about a lost dog or looking for an adopter, how to care for and raise a dog, adjust the dog's character to the owner. The topic of the third communication event is to discuss the regulations from the government regarding the use of a leash or leash on dogs.

The purpose of forming the Jakarta Dog Lovers Communi ty is to promote dogs in the midst of social life and to socialize the movement to care for and love animals, especially domestic dogs. These two objectives mean that dogs are not only pets, but can be useful in people's lives, especially as friends, friends, and human families.

Meanwhile, the purpose of participants or members in joining this community is to become more knowledgeable and obtain information about dogs, exchange ideas through sharing, and dog and dog owners can socialize with one another.

The Jakarta Dog Lovers community has different activities, this of course makes the location setting different. However, the Jakarta Dog Lovers Community has a basecamp located in Taman Kodok, Menteng - Central Jakarta. The Frog Park is one of the basecamp of this community because this park is located in the city center, making it easier for members to gather.

Participants in the Jakarta Dog Lovers Community are members or participants consisting of different ages, ethnicities, religions, professions, and domiciles. Participants in this community are divided into 2 categories, namely the full member category which is a category that is subject to registration fees and annual fees, while the regular member category is a category that is free of any fees.

Regular members are members who are not charged to join the Communi ty, and these members will only be invited to the group chat on Telegram messenger. Meanwhile, full members will also be invited to the group chat on Telegram messenger and will be charged an administrative fee for member registration 
of IDR 300,000 with an annual fee of IDR 100,000 .

The form of messages contained in the Jakarta Dog Lovers Community consists of verbal messages, non-vocal verbal messages, and non-verbal messages. The form of this message is in the form of sharing between dog owners both in person and through social media, as well as bringing dogs in every activity. This is to show that he is a dog lover.

The content of the message communicated in the Jakarta Dog Lovers Communi ty is that dogs are not pets, but dogs are considered friends, friends and family to humans. The contents of the message are shared with members and the communi ty through various activities carried out in this community.

The sequence of actions in the Jakarta Dog Lovers Community has 3 stages in establishing a relationship with fellow community members. The first stage is the introduction stage of community members in general. The second stage is the stage of establishing relationships with fellow community members. The third stage is maintaining good relations between community members.

The interaction principle in this study is that members of the Jakarta Dog Lovers Community have a calling word for fellow members in the community. Community members, in addressing fellow dog owners, especially fellow members, use the term "onty" and "ongkel" or often shortened to the term "tingkel".

The norms of interpretation that exist in the Jakarta Dog Lovers Community are in the form of general knowledge about dogs, and share the value with its members that dogs are considered friends, friends, and family members and dogs are considered haram if dog meat is eaten. In this component, the community also has norms adopted by community members when they want to carry out activities.

Researchers see based on the communication components according to the ethnographic perspective of communicati o $n$ which are interrelated to form a communication activity in which members act in carrying out activities based on their meaning of dogs which are considered friends, friends, and family members.

Communication competence in the Jakarta Dog Lovers Community is seen with 2 analysis blades, namely linguistic knowledge and interaction skills. Linguistic knowledge to see the role of slang or everyday Indonesian in creating several terms that are shared in the communi ty. Meanwhile, interaction skills to see the ability of member s to interact in the communi ty.

\section{CONCLUSION}

The Jakarta Dog Lovers Community is a community that serves as a gathering place for all types of dogs, including purebred dogs and village dogs. This community was founded based on the same vision and mission in promoting dogs in the midst of social life. This communi ty aims to make all dog lovers become committed dog owners and more responsible in caring for and caring for dogs.

Ethnographic communication that occurs in the Jakarta Dog Lovers Communi ty is centered on activities carried out by members or participants in the community. The form of activities carried out in this community is routine gathering activities every weekend, conducting charity activities, participating and being active in campaign activities, and conducting educational activities.

Activities in the Jakarta Dog Lovers Community are influenced by the communication components that make up the 
communication activities in it. The communication components are in the for $m$ of communicative event genre or type, communicative event topic, purpose and function of the event, setting, participant, message form, message content, action sequence, interaction rules and interpretation norms.

Communication activities carried out by this community are also supported by the competence of members when interacting in the Jakarta Dog Lovers Community. This competency looks at 2 aspects, namely linguistic knowledge and interaction skills in the community. This is evidence from the ethnographic communication that occurs in the Jakarta Dog Lovers Communi ty.

In the Jakarta Dog Lovers Community Communication Ethnography study, researchers determined cultural themes based on cognitive principles. The cognitive principle is a general assumption about the experience of community members. This can be seen in the determination of cultural themes regarding the formation of dog animal meanings in the Jakarta Dog Lovers Communi ty. This formed meaning states that all dogs, both mutt and purebred dogs, are not only pets, but are considered friends, friends and family members.

Based on an academic perspective, the researcher suggests that research on the topic of the dog lovers community can be further developed. Based on an academic perspective, the researcher suggests that research on the topic of the dog lovers community can be further developed. This results in many aspects of the topic of the dog lovers community, especially the Jakarta Dog Lovers Community which can be researched in the future.

Aspects that can be developed in the topic of the dog lovers community, such as in the aspects of phenomenology, interpersonal communication, or group communication in the Jakarta Dog Lovers Community. In this research topic can also develop communication theories, such as the theory of developing relationships between communi ty members.

In addition, the researcher also suggests paying attention to an objective point of view in researching the Jakarta Dog Lovers Community. This is because the topic is interesting, especially in an effort to assist the government in creating welfare for domestic animals, especially dogs.

Researchers see that in the Jakarta Dog Lovers Community, there are often differences of understanding. This can be seen from the mandatory use of the leash on dogs. Some members still ignore these rules because they feel their dogs are tame. Therefore, researchers suggest that the rules of using leash for dogs are more socialized to participants or members of this community.

The researcher also suggested that the Jakarta Dog Lovers Community could hold more charity activities to help dogs that need assistance. Then the researchers also suggested that more interactive public education activities in raising and caring for dogs. The researchers also suggest that more often carry out campaign activities so that the messages conveyed by this community can be more accepted by the wider community.

\section{REFERENCES}

\section{Book:}

Alyusi, Shiefty Dyah (2016), Media Sosial: Interaksi, Identitas dan Modal Sosial, Edisi Pertama, Cetakan ke-1, Jakarta: Kencana Prenada Media Group.

Azw ar, Saifuddin (2011), Metode Penelitian, Yogyakarta: Pustaka Pelajar.

Cangara, Hafied (2010), Pengantar Ilmu Komunikasi, Jakarta: PT RajaGrafindo Persada. 
Kertajaya, Hermaw an (2008), Arti komunitas, Jakarta: Gramedia Pustaka Utama.

Kriyantono, Rachmat (2015), Public Relations, Issue \& Crisis Management: Pendekatan Critical Public Relations, Etnografi Kritis \& Kualitatif, Cetakan ke-1, Jakarta: Prenada Media Group.

Kuswarno, Engkus (2011), Etnografi Komunikasi: Pengantar dan Contoh Penelitiannya, Bandung: Widya Padjadjaran.

Littlejohn, Stephen W. dan Karen A. Foss (2012), Teori Komunikasi, Edisi 9, Terjemahan oleh Mohammad Yusuf Hamdan, Jakarta: Penerbit Salemba Humanika.

Spradley, James P. (2007), Metode Etnografi, Edisi Kedua, Cetakan I, Yogyakarta: Tiara Wacana.

The sis:

Decynta (2016), Skripsi: Etnografi Komunikasi Komunitas Fujoshi Indonesia dalam Melakukan Kegiatan Shipping, Institut Bisnis dan Informatika Kwik Kian Gie

Gumilar (2007), Skripsi: Komunikasi Kelompok Pada Komunitas Geng Motor XTC Bandung (Studi Kualitatif dengan Pendekatan Etnografi Komunikasi Mengenai Komunikasi Kelompok Komunitas Geng Motor XTC di Lingkungan daerah salah satu SMUN di Bandung dalam Mempertahankan / Membangun Solidaritas Kelompok), Fakultas Il mu Komunikasi Universitas Islam Bandung.

Permatasari, Citra Ayu Indah (2016), Skripsi: Etnografi Komunikasi Komunitas Konsumen Penyayang Kucing: Studi Pada Komunitas Pecinta Kucing Jakarta (KPKJ), Fakultas Ekonomi dan Ilmu Sosial Universitas Bakrie.

\section{Inte rne t:}

Anjing Kita, Jakarta Dog Lovers, diakses 16 Oktober 2017 http://anjingki ta.com/artikel/30880/jak arta-dog-lovers.

Artikel Sains, Teknik Analisis dalam Penelitian Etnografi, diakses 8 Desember 2017, http://w w w .artikelsains.com/2015/01/t eknik-analisis-dalam-penelitian html.

Facebook, Jakarta Dog Lovers, diakses 16 Oktober 2017 , https://ww w.facebook.com/jakartadogl overs/.

Instagram, Jakarta Dog Lovers, diakses 16 Oktober 2017, https://w w w .instagramcom/jakartadog lovers $/ ? \mathrm{hl}=\mathrm{en}$.

Jakarta Dog Lovers, Jakarta Dog Lovers: We Are Dog Lovers - Together We Can, diakses $17 \quad$ Oktober 2017, https://ww w.jakartadoglovers.com/abo ut/

Jitu News, Jakarta Dog Lovers: Wadah Pencinta Anjing di Ibu Kota, diakses 20 Oktober

2017,http://w w w.jitunew s.com/read/36 572/jakarta-dog-lovers-w adah-pecintaanjing-di-ibu-kota.

Pengertian Menurut Para Ahli, Pengertian komunitas dan contohnya, diakses 25 November 2017 , http $/ /$ www.pengertian menurutparaahli. net /pengertian-komun itas-dan-contohnya/

Perkin, Perkin: Perkumpulan Kinologi Indonesia, diakses $\quad 17 \quad$ Oktober 2017, http $/ /$ www.perkin.or.id/

Pets Id, Wawancara Singkat Pets.Id Bersama Ketua Jakarta Dog Lovers, diakses 10 Oktober 2017 , http//blog. pets. id/ wawancara-singkatpets-id-bersama-ketua-jakarta-do g-lovers/.

Video Advertisements: The Case of bell). Dalam Discurso \& Sociedad,1394), hlm

765-797. 
http://w w w .dissoc.org/ediciones/v13n0 4/DS13(4)Screti.

Tumpi. 2017. 14 Tipe Shot Dalam Pengambilan Gambar Film, (Online), (https://tumpi.id/14-tipe-shot-dalampengambilan-gambar-fil $\mathrm{m} /$. Diakses 18 Februari 2020).

Udasmoro, W. (Ed.). (2017). Dari Doing Ke Undoing Gender (Teori Dan Praktik Dalam Kajian Feminisme). Gadjah Mada University Press.

VIVA. 2018. Blued, Aplikasi Pecinta Sesama Jenis dengan 27 Juta Pengguna, (Online), (https://w w w .viva.co.id/arsip/996784blued-aplikasi-pecinta-sesama-jenisdengan-27-juta-pengguna. Diakses 9 November 2019).

Woodward, Kathryn (ed.). 2002. Identity and Difference. London: SAGE Publications.

Yulius, Hendri. 2019. C*BUL: Perbincangan Serius tentang Seksualitas Kontemporer. Tangerang Selatan: Marjin Kiri. 